\title{
Evaluation of the aldose reductase inhibitor fidarestat on ischemia-reperfusion injury in rat retina
}

\author{
IRINA G. OBROSOVA ${ }^{1}$, YURY MAKSIMCHYK ${ }^{1}$, PAL PACHER ${ }^{2}$, ELISABET AGARDH ${ }^{4}$, \\ MAJ-LIS SMITH ${ }^{4}$, AZZA B. EL-REMESSY ${ }^{3}$ and CARL-DAVID AGARDH ${ }^{4}$
}

\author{
${ }^{1}$ Pennington Biomedical Research Center, Louisiana State University System, Baton Rouge, LA; ${ }^{2}$ Section on Oxidative \\ Stress Tissue Injury, Laboratory of Physiological Studies, NIH/NIAAA, Bethesda, MD; ${ }^{3}$ Program in Clinical and \\ Experimental Therapeutics, College of Pharmacy, University of Georgia, Augusta, GA, USA; ${ }^{4}$ The Department \\ of Clinical Sciences, University Hospital MAS, Lund University, Malmö, Sweden
}

Received February 24, 2010; Accepted March 29, 2010

DOI: 10.3892/ijmm_00000445

\begin{abstract}
This study evaluated the effects of retinal ischemiareperfusion (IR) injury and pre-treatment with the potent and specific aldose reductase inhibitor fidarestat on apoptosis, aldose reductase and sorbitol dehydrogenase expression, sorbitol pathway intermediate concentrations, and oxidative-nitrosative stress. Female Wistar rats were pre-treated with either vehicle (N-methyl-D-glucamine) or fidarestat, $32 \mathrm{mgkg}^{-1} \mathrm{~d}^{-1}$ for both, in the right jugular vein, for 3 consecutive days. A group of vehicle- and fidarestat-treated rats were subjected to 45-min retinal ischemia followed by $24-\mathrm{h}$ reperfusion. Ischemia was induced $30 \mathrm{~min}$ after the last vehicle or fidarestat administration. Retinal IR resulted in a remarkable increase in retinal cell death. The number of TUNEL-positive nuclei increased 48 -fold in the IR group compared with non-ischemic controls $(\mathrm{p}<0.01)$, and this increase was partially prevented by fidarestat. AR expression (Western blot analysis) increased by $19 \%$ in the IR group $(\mathrm{p}<0.05)$, and this increase was prevented by fidarestat. Sorbitol dehydrogenase and nitrated protein expressions were similar among all experimental groups. Retinal sorbitol concentrations tended to increase in the IR group but the difference with non-ischemic controls did not achieve statistical significance $(\mathrm{p}=0.08)$. Retinal fructose concentrations were 2.2-fold greater in the IR group than in the nonischemic controls $(\mathrm{p}<0.05)$. Fidarestat pre-treatment of rats subjected to IR reduced retinal sorbitol concentration to the levels in non-ischemic controls. Retinal fructose concentrations were reduced by $41 \%$ in fidarestat-pre-treated IR group vs. untreated ischemic controls $(\mathrm{p}=0.0517)$, but remained $30 \%$ higher than in the non-ischemic control group. In conclusion, IR injury to rat retina is associated with a dramatic increase in cell death, elevated AR expression and sorbitol pathway
\end{abstract}

Correspondence to: Dr Irina G. Obrosova, Pennington Biomedical Research Center, Louisiana State University System, 6400 Perkins Road, Baton Rouge, LA 70808, USA

E-mail: obrosoig@pbrc.edu

Key words: aldose reductase, apoptosis, fidarestat, nitrated proteins, retinal ischemia-reperfusion, sorbitol dehydrogenase intermediate accumulation. These changes were prevented or alleviated by the AR inhibitor fidarestat. The results identify $\mathrm{AR}$ as an important therapeutic target for diseases involving IR injury, and provide the rationale for development of fidarestat and other AR inhibitors.

\section{Introduction}

Sorbitol pathway of glucose metabolism consists of two reactions, aldose reductase (AR)-catalyzed NADPH-dependent reduction of glucose to its sugar alcohol, sorbitol, followed by sorbitol dehydrogenase(SDH)-catalyzed NAD-dependent oxidation of sorbitol to fructose. For almost 50 years after its discovery (1), it has been considered that activation of the sorbitol pathway of glucose metabolism is a direct consequence of hyperglycemia or hypergalactosemia. This notion has been supported by numerous studies with AR inhibitors in animal models of diabetes and galactose feeding which provided evidence for the important role of increased sorbitol pathway activity in diabetic or diabetes-like complications including cataract $(2-4)$, retinopathy $(2,5,6)$, peripheral and autonomic neuropathy (7-11), and nephropathy $(12,13)$. The important role for the first enzyme of the sorbitol pathway, AR, in several diabetic complications has further been confirmed in studies with AR-overexpressing and AR-knockout mice (14-17).

Recent reports suggest that increased sorbitol pathway activity is also involved in the pathogenesis of diseases that are not accompanied by hyperglycemia including atherosclerosis (18), cancer (19), and a number of inflammatory conditions and disorders such polymicrobial sepsis (20), asthma (21) and uveitis (22). Evidence for the important role of this mechanism in ischemia-reperfusion (IR) injury, and, in particular, in cardiac $(23-25)$ and, recently, retinal $(26,27)$ IR injury is emerging.

In human disease, retinal IR injury takes place when retinal blood flow is interrupted for a long period of time and then restarted. It occurs in transient ischemia-related diseases, such as central retinal artery occlusion, angle-closure glaucoma, amaurosis fugax, as well as in diabetes, atherosclerosis, and hypertension (26-29). Retinal ischemia and diabetic retinopathy share many pathophysiological and pathological features 
including but not limited to b-wave abnormalities in the electroretinogram $(30,31)$, glial activation $(32,33)$, retinal neuronal and ganglion cell degeneration $(26,34)$, increased vascular permeability and breakdown of blood-retinal barrier $(35,36)$, edema $(26,37)$, capillary cell loss $(38,39)$, and accelerated angiogenesis $(40,41)$. Also note, that whereas retinal ischemia plays an important role in the progression of diabetic retinopathy towards its advanced, or proliferative stage (41), its treatment with scatter laser photocoagulation restoring oxygen supply is associated with the development of sightthreatening macular edema (42). Sixty percent of eyes treated with scatter photocoagulation showed an increase in foveal thickness, detectable by a scanning retinal thickness analyzer, after photocoagulation (42).

A recent study in AR-deficient mouse model implicated increased AR activity in neuronal loss and edema associated with retinal IR injury (26). In the same report, IR-associated increase in TUNEL positivity in retinal ganglion cell and inner neuronal layers, retinal thickening, as well as cytoarchitectural disorganization were prevented or markedly reduced by the ARI fidarestat. In our recent experiments in the rat model of retinal IR injury, pre-treatment with fidarestat alleviated inflammatory response (27). The present study conducted in the same animal model evaluated the effects of IR injury and fidarestat pre-treatment on retinal apoptosis, AR and sorbitol dehydrogenase (SDH) protein expressions, sorbitol pathway intermediate concentrations, and oxidative-nitrosative stress.

\section{Materials and methods}

Reagents. Unless otherwise stated, all chemicals were of reagent-grade quality, and were purchased from Sigma Chemical Co., St. Louis, MO. Rabbit polyclonal antinitrotyrosine antibody was purchased from Upstate, Lake Placid, NY, USA. Mouse anti-AR monoclonal antibody was purchased from Santa Cruz Biotechnology, Santa Cruz, CA, USA. Mouse anti-SDH monoclonal antibody was obtained from Abcam, Cambridge, MA, USA. ApopTag ${ }^{\circledR}$ Peroxidase In Situ Apoptosis Detection kit was purchased from Chemicon International, Inc., Temecula, CA. Other reagents for immunohistochemistry were purchased from Dako Laboratories, Inc., Santa Barbara, CA.

Animals. The experiments were performed in accordance with regulations specified by The Guide for the Care and Handling of Laboratory Animals (NIH Publication no. 85-23) and The Animal Ethics Committee of Malmö/Lund. Female Wistar rats (Taconic Europe, Ry, Denmark), body weight 200-250 g, were housed in individually ventilated cages in a temperature-controlled environment with free access to food and water and a 12-h light-dark cycle. The rats have randomly been divided into groups pre-treated with the ARI fidarestat (Sanwa Kagaku Kenkyusho Co., Nagoya, Japan), at 32 mgkg $^{-1} \mathrm{~d}^{-1}$ i.v. or the vehicle N-methyl-D-glucamine (NMDG). A group of vehicle- and fidarestat-pre-treated rats were then subjected to $45-$ min retinal ischemia followed by $24 \mathrm{~h}$ of reperfusion.

Administration of fidarestat and NMDG. On day 1, the animals in the fidarestat and NMDG groups were anesthetized with $3 \%$ isoflurane (IsoFlo Vet, Orion Pharma Animal Health, Sollentuna, Sweden). A neck incision was made and the right jugular vein was exposed and catheterized to allow repeated i.v. injections. The catheter was tunneled under the skin to appear through a small cut in the neck scruff. After injection, the catheter was closed and replaced under the skin and wounds were sutured. Injections were repeated on day 2 under $2 \%$ isoflurane anesthesia. On day 3, the animals were anesthetized with fentanyl $(300 \mu \mathrm{g} / \mathrm{kg}$ i.p., B. Braun, Melsungen, Germany) followed by medetomidin (300 $\mu \mathrm{g} / \mathrm{kg}$ i.p., Domitor Vet, Orion Pharma Animal Health, Sollentuna, Sweden), and a third dose of fidarestat or NMDG was given $30 \mathrm{~min}$ before induction of ischemia.

Induction of ischemia and reperfusion. The pupils were dilated with cyclopentolate $1 \%\left(\right.$ Cyclogyl $^{\circledR}$, Alcon, Stockholm, Sweden) followed by the application of a local anesthetic, tetracaine 1\% (Tetrakain Chauvin, Novartis Ophthalmic, Copenhagen, Denmark) which allowed the direct observation of retinal blood flow under a stereomicroscope. Retinal ischemia was induced $30 \mathrm{~min}$ after the vehicle or fidarestat injection, by careful application of a 5-0 silk suture (Ethicon, Sollentuna, Sweden) around the vessels and the accompanying optic nerve of the left eye as described (43). The ligature was tightened until complete cessation of the retinal blood flow occurred. The right eye served as a non-ischemic control. During induction of ischemia, rats were placed in cages supplied with a heating pad, to avoid a decrease in body temperature. After $45 \mathrm{~min}$, the ligature was carefully removed. After confirmation of restoration of retinal blood flow, anesthesia was reversed by bupenorfin $(30 \mu \mathrm{g} / \mathrm{kg}$ s.c., Temgesic ${ }^{\circledR}$, Schering-Plough, Kenilworth, NJ, USA) and atipamezol (1 mg/kg s.c., Antisedan Vet, Orion Pharma Animal Health, Sollentuna, Sweden), and reperfusion continued for $24 \mathrm{~h}$, after which all animals were sacrificed.

Euthanasia and retinal dissection. The rats were sedated by $\mathrm{CO}_{2}$, and were immediately sacrificed by cervical dislocation. In approximately half of animals in each experimental group, both eyes were rapidly enucleated, the lenses were removed, and the retinas gently peeled off from the pigment epithelium, snap-frozen in liquid nitrogen, and stored at $-80^{\circ} \mathrm{C}$ prior to analysis of sorbitol pathway intermediate concentrations and $\mathrm{AR}, \mathrm{SDH}$, and nitrated protein expression. In the other half, the eyes were fixed in 4\% paraformaldehyde in PBS and later used for preparation of flat mounted retinas and quantitation of apoptosis.

\section{Specific methods}

Retinal glucose and sorbitol pathway intermediate concentrations. Retinal glucose, sorbitol and fructose concentrations were assessed by spectrofluorometric enzymatic methods with hexokinase/glucose 6-phosphate dehydrogenase, sorbitol dehydrogenase, and fructose dehydrogenase as we described in detail $(44,45)$.

Western blot analysis of AR, SDH, and nitrated proteins. Western blot analyses of AR, SDH, and nitrated proteins in individual retinas (one retina from each rat) were performed as described previously $(13,33)$. Protein bands were visualized with the BM Chemiluminescence Blotting Substrate (POD) (Roche, Indianapolis, IN). Membranes were then stripped and reprobed with $\beta$-actin antibody to confirm equal protein 
A.

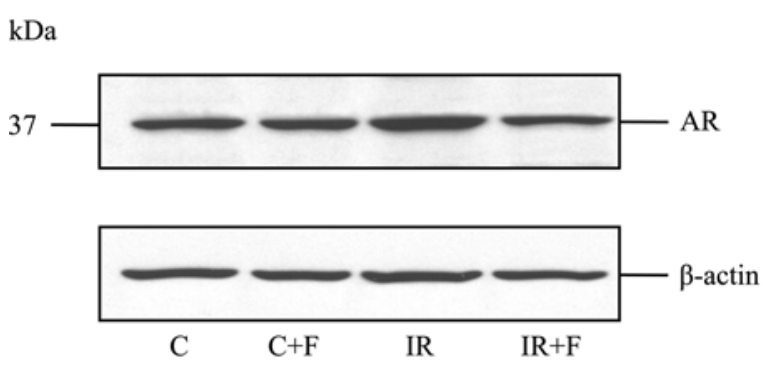

B.

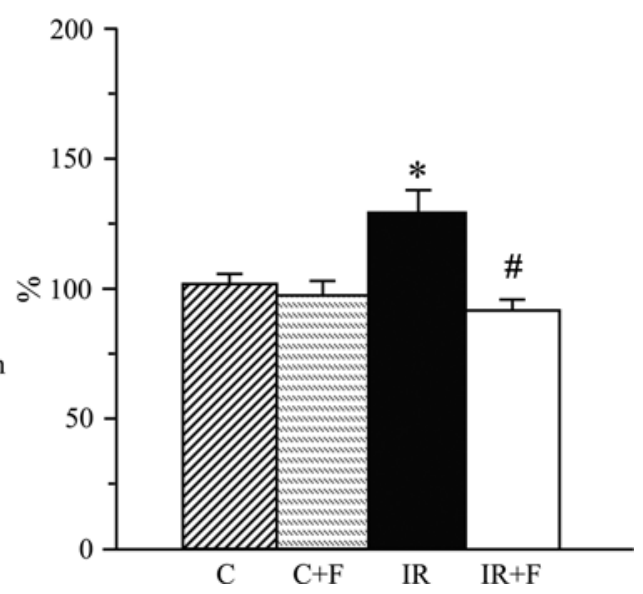

Figure 1. Representative Western blot analysis of retinal aldose reductase expression (A) and aldose reductase protein content (densitometry, B) in nonischemic and ischemia-reperfusion-subjected retinas after vehicle or fidarestat pre-treatment. C, control; IR, ischemia-reperfusion; F, fidarestat. Mean \pm SEM, $\mathrm{n}=4-5$ per group. ${ }^{*} \mathrm{p}<0.05$ vs. the non-ischemic control group, ${ }^{*} \mathrm{p}<0.05$ vs. the vehicle-pre-treated ischemia-reperfusion group.

A.

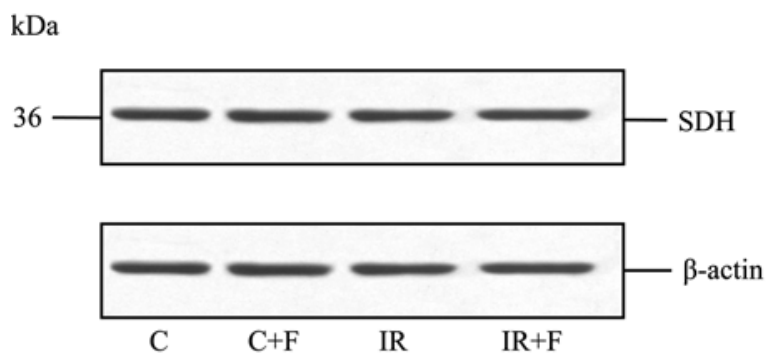

B.

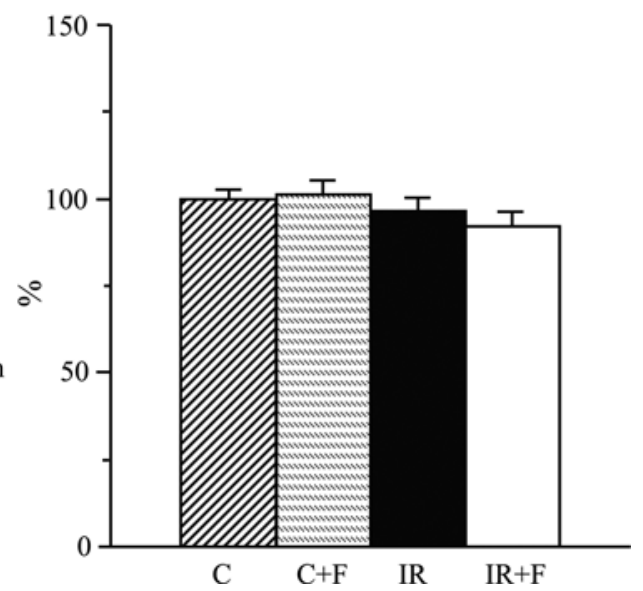

Figure 2. Representative Western blot analysis of retinal sorbitol dehydrogenase expression (A) and sorbitol dehydrogenase protein content (densitometry, B) in non-ischemic and ischemia-reperfusion-subjected retinas after vehicle or fidarestat pre-treatment. C, control; IR, ischemia-reperfusion and F, fidarestat. Mean \pm SEM, $\mathrm{n}=5$ per group.

loading. The data were quantified by densitometry (Quantity One 4.5.0 software, Bio-Rad Laboratories, Richmond, CA).

Immunohistochemical assessment of TUNEL positivity. All flat mounted retinas were processed by a single investigator and evaluated blindly. TUNEL positivity was quantified with the ApopTag ${ }^{\circledR}$ Peroxidase In Situ Apoptosis Detection kit as described $(34,46)$.

Statistical analysis. The results are expressed as mean \pm SEM. Data were subjected to equality of variance F test, and then to $\log$ transformation, if necessary, before one-way analysis of variance. Where overall significance $(\mathrm{p}<0.05)$ was attained, individual between group comparisons for multiple groups were made using the Student-Newman-Keuls multiple range test. When between-group variance differences could not be normalized by log transformation (data sets for body weights and blood glucose), the data were analyzed by the nonparametric Kruskal-Wallis one-way analysis of variance, followed by the Bonferroni/Dunn test for multiple comparisons. Significance was defined at $\mathrm{p} \leq 0.05$.

\section{Results}

Both $\mathrm{AR}$ and SDH expressions in the retina were clearly identifiable in all experimental conditions. Retinal IR injury was associated with a $19 \%$ increase in AR protein expression $(\mathrm{p}<0.05$ vs. the non-ischemic control group, Fig. 1). Fidarestat pre-treatment prevented IR-associated AR protein expression ( $p<0.05$ vs. the vehicle-pretreated ischemic group). Vehicle pre-treatment did not affect AR expression in non-ischemic retina.

Retinal SDH expression did not differ among the experimental groups (Fig. 2). Retinal glucose concentration tended 
Table I. Retinal glucose and sorbitol pathway intermediate concentrations (nmol/mg protein) in non-ischemic and ischemia-reperfusion-subjected rat retinas after vehicle or fidarestat pretreatment.

\begin{tabular}{lccc}
\hline & \multicolumn{3}{c}{ Variable } \\
\cline { 2 - 4 } Group & Glucose & Sorbitol & Fructose \\
\hline Control + Vehicle & $12.3 \pm 2.1$ & $0.9 \pm 0.1$ & $7.3 \pm 2.0$ \\
Control + Fidarestat & $11.2 \pm 1.5$ & $0.8 \pm 0.1$ & $8.9 \pm 1.7$ \\
IR & $16.9 \pm 1.0$ & $1.4 \pm 0.2^{\mathrm{a}}$ & $16.1 \pm 2.4^{\mathrm{a}}$ \\
IR + Fidarestat & $9.8 \pm 1.0^{\mathrm{c}}$ & $0.9 \pm 0.1^{\mathrm{b}}$ & $9.5 \pm 2.1$ \\
\hline
\end{tabular}

Data are means \pm SEM, $n=4-9$ per group. IR, ischemia-reperfusion ${ }^{\mathrm{a}} \mathrm{p}<0.05$ vs controls; ${ }^{\mathrm{b}, \mathrm{c}} \mathrm{p}<0.05, \mathrm{p}<0.01$ vs. untreated group of mice.

to increase in the IR group (probably, due to impaired aerobic glucose metabolism), but the difference with the non-ischemic group did not achieve statistical significance (Table I). Retinal sorbitol and fructose concentrations were increased by $56 \%$ and $120 \%$ in the IR group ( $<<0.05$ vs. the non-ischemic control group). Pre-treatment with fidarestat completely prevented IR-induced changes in retinal glucose and sorbitol concentrations. Retinal fructose concentrations were $41 \%$ lower in fidarestat-pre-treated rats compared with the vehicle-pre-treated group ( $\mathrm{p}=0.052)$, but still remained $30 \%$ higher than in nonischemic controls $(\mathrm{p}=0.44)$. Vehicle pre-treatment did not affect retinal glucose and sorbitol pathway intermediate concentrations in the non-ischemic rats.

Retinal IR injury resulted in a dramatic increase in cell death (Fig. 3). The number of TUNEL-positive cells per retina was 48 -fold greater in the IR group than in the non-ischemic controls $(\mathrm{p}<0.01)$. Pre-treatment with fidarestat reduced TUNEL positivity 6.1-fold, compared with the vehicle-pretreated group $(\mathrm{p}<0.01)$. However, the number of TUNELpositive cells was 7.8-fold greater in fidarestat-pre-treated IR-subjected retinas compared with the non-ischemic controls $(\mathrm{p}<0.01)$. Retinal nitrated protein levels were similar among non-ischemic and IR-subjected retinas pre-treated with vehicle or fidarestat (Fig. 4).

\section{Discussion}

The results discussed herein implicate increased sorbitol pathway activity in accelerated cell death associated with retinal IR injury. Retinal IR induced AR protein overexpression and sorbitol pathway intermediate accumulation that were completely or partially prevented by pre-treatment with the ARI fidarestat. Fidarestat markedly reduced IRrelated retinal cell death. Neither IR injury nor fidarestat-pretreatment were associated with any changes in the whole retina nitrated protein expression.

In the present study, IR injury tended to increase retinal glucose concentrations, probably due to decreased glucose metabolism under ischemic conditions. Fidarestat pretreatment prevented IR-induced increase in retinal glucose. Whereas the mechanism underlying this phenomenon in IRsubjected retina has not been clarified, an ARI treatment is

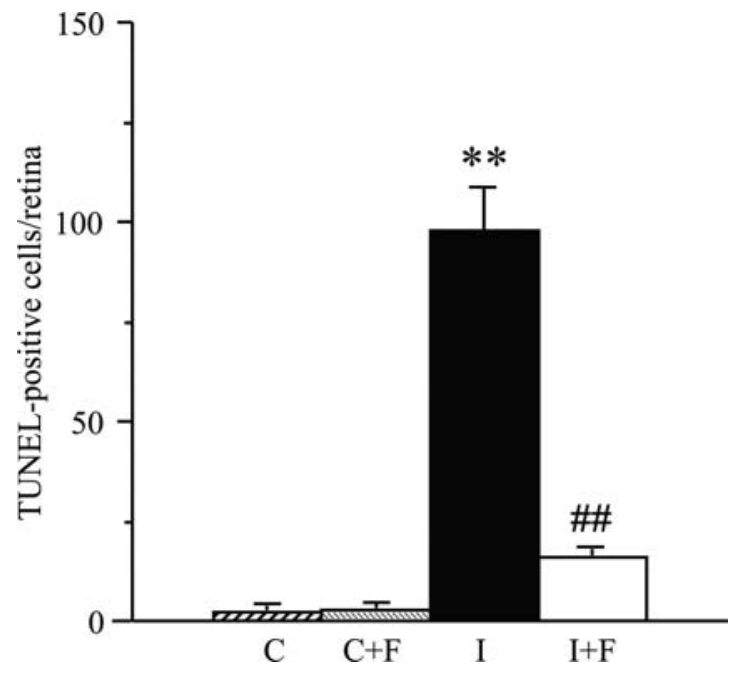

Figure 3. TUNEL-positive cell counts in non-ischemic and ischemia-reperfusion-subjected retinas after vehicle or fidarestat pre-treatment. C, control; IR, ischemia-reperfusion; $\mathrm{F}$, fidarestat. Mean \pm SEM, $n=5-9$ per group, ${ }^{* *} \mathrm{p}<0.01$ vs. the non-ischemic control group; ${ }^{\# \#} \mathrm{p}<0.01$ vs. the vehicle-pretreated IR group.

known to be associated with an increase in retinal cytosolic and mitochondrial $\mathrm{NAD}^{+} / \mathrm{NADH}$ ratios in the diabetic rat model (45). Such changes in free cytosolic and mitochondrial $\mathrm{NAD}^{+} / \mathrm{NADH}$ redox states accelerate glycolysis and tricarboxylic acid cycle thus promoting intracellular glucose utilization.

The findings of increased sorbitol pathway activity manifest by sorbitol and fructose accumulation in retinal IR model in the present study are in line with previous reports demonstrating beneficial effects of ARIs on cardiac IR injury $(23-25,47)$. The mechanisms underlying IR-associated sorbitol pathway activation are not understood; furthermore, it is unclear whether it occurs because of ischemia, reperfusion, or both phases of IR injury. A recent demonstration of increased sorbitol and fructose concentrations in the muscle and kidney of mice subjected to hindlimb ischemia (48) suggests that ischemia rather than reperfusion leads to sorbitol pathway activation. In another study (26), IR, but not ischemia alone, was associated with increased cardiac fructose concentration, whereas sorbitol concentrations were indistinguishable in non-ischemic hearts and those subjected to ischemia alone or IR. Pre-treatment with fidarestat counteracted IR-induced retinal sorbitol pathway intermediate accumulation in the present study, consistent with the effects of fidarestat (48) and another ARI (25) on ischemia- or IRassociated increase in sorbitol and/or fructose concentrations in the muscle, kidney, and heart in the two above-mentioned reports.

Ischemia- or IR-related sorbitol pathway activation is not necessarily associated with increased AR expression. AR expression in IR-subjected retinas was increased in the present study, consistent with induction of AR immunoreactivity in the retinal inner neuronal layer by transient ischemia in another report (26). In contrast, no induction in AR expression was found in the mouse ischemic kidney or muscle (48).

The role for the second enzyme of sorbitol pathway, SDH, in diabetic complications has been an area of intense controversy for more than ten years, and the findings suggesting 
A.

$\mathrm{kDa}$

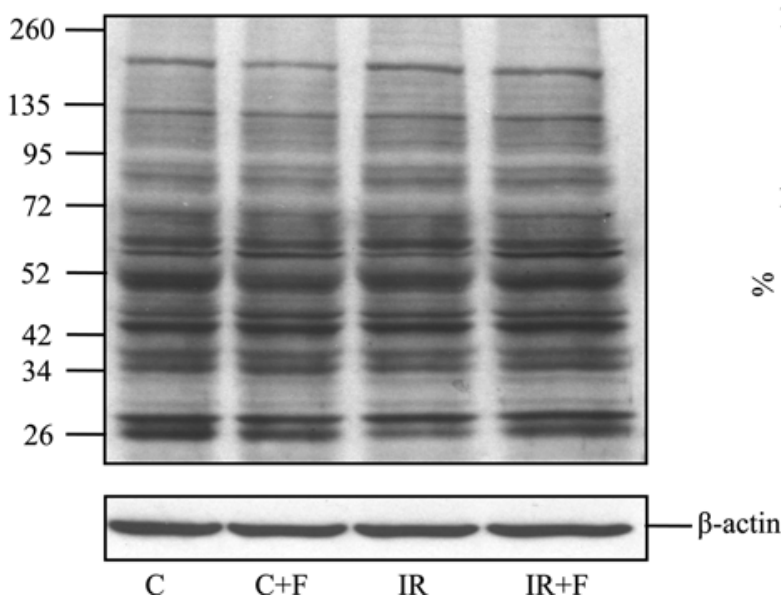

B.

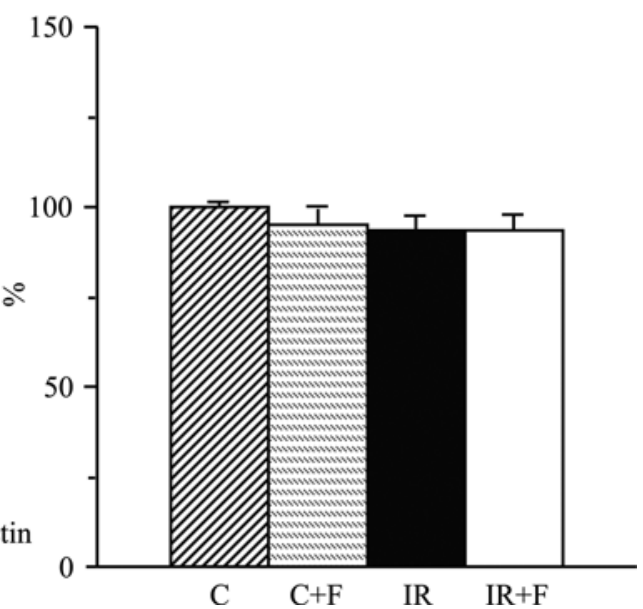

Figure 4. Representative Western blot analysis of nitrated protein expression (A) and nitrated protein content (densitometry, B) in non-ischemic or ischemiareperfusion-subjected retinas after vehicle or fidarestat pre-treatment. $\mathrm{C}$, control; $\mathrm{I}$, ischemia-reperfusion and $\mathrm{F}$, fidarestat. Mean $\pm \mathrm{SEM}$, $\mathrm{n}=5$ per group.

protective $(49-53)$ or detrimental $(54,55)$ functions of this enzyme activity or its minor importance $(56,57)$ in the pathogenetic process have been produced by different laboratories. Two groups $(25,58)$ obtained evidence of the important role for this enzyme in cardiac IR injury. In contrast, SDH does not seem to play an important role in retinal IR injury as, in contrast to AR-deficient or fidarestat-pre-treated mice, SDHdeficient or the SDH inhibitor CP-470,711-pre-treated mice were not protected from apoptotic neuronal death or edema caused by transient retinal ischemia (26). In the present study, SDH expression in the whole retina was unchanged by IR, whereas SDH immunoreactivity in inner neuronal layer was found decreased by transient retinal ischemia in the aforementioned report (26).

Studies in the field of diabetic complications suggest that increased AR activity contributes to multiple biochemical changes in tissue-sites for diabetic complications including retina (reviewed in ref. 59). In particular, increased AR activity leads to vascular endothelial growth factor formation $(6,17)$, mitochondrial and cytosolic $\mathrm{NAD}^{+} / \mathrm{NADH}$ imbalances $(10,45)$ and energy deficiency $(10,60), \mathrm{Ca}^{2+}$ overload (61), increased formation of precursors of advanced glycation endproducts (AGE), i.e., fructose, fructose 3-phosphate (62), methylglyoxal (63), and 3-deoxyglucosone (64), and AGE per se $(65,66)$. Increased AR activity also contributes to diabetes-associated diversion of the glycolytic flux from glyceraldehyde 3 -phosphate dehydrogenase towards the formation of $\alpha$ glycerophosphate (51), the protein kinase $\mathrm{C}$ activator diacylglycerol (67), and protein kinase $\mathrm{C}$ activation (68). In recent years, AR has been implicated in activation of mitogenactivated protein kinases (69), poly(ADP-ribose) polymerase [PARP $(13,70)]$, and cyclooxygenase-2 (71), as well as nuclear factor- $\mathrm{\kappa B}(\mathrm{NF}-\kappa \mathrm{B})$ and activator protein-1 (72). Many of these mechanisms, and, in particular, $\mathrm{NAD}^{+} / \mathrm{NADH}$ redox imbalances, accumulation of intracellular $\mathrm{Ca}^{2+}$, activation of PARP and cyclooxygenase-2 (COX-2), and activation of NF$\kappa \mathrm{B}$ and resultant increase in cytokine production and proinflammatory response, have also been implicated in IR injury $(25,58,73-75)$. Cytokines (75), PARP and COX-2 activations
$(73,74)$, and overexpression of c-Jun N-terminal kinase (76) have also been implicated in IR-induced retinal apoptosis. Whereas relations among increased AR and these factors in IR still remain to be explored, it is not excluded that retinoprotective effect of fidarestat is mediated through one of the afore-mentioned mechanisms. Note, that PARP activation manifest by increased poly(ADP-ribose) immunoreactivity, was detected in retinal ganglion cell layer and inner neuronal layer of wild-type but not AR-deficient mice (26). A complete or partial prevention of retinal apoptosis has been reported in ARI-treated diabetic animals $(3,4,17)$, ARI-treated high glucose exposed retinal pericytes $(77,78)$, as well as ARItreated and AR-deficient mice subjected to IR injury (26).

In the present study, IR-related increase in retinal cell death and its partial prevention by fidarestat pre-treatment were not related to the corresponding changes in nitrated protein expression, a stable footprint of peroxynitrite damage (79), in the whole retina. The latter is quite surprising considering that peroxynitrite plays a role in IR injury in general (79), and protein nitration has been identified as a contributing factor to retinal IR injury (80) as well as to apoptosis associated with diabetic retinopathy (81). Also, increased AR activity, a major factor responsible for impaired antioxidative defense (reviewed in ref. 59), has been found to contribute to nitrosative stress in diabetic $(4,13,17,70)$ and IR $(25,26)$ models and high glucose-exposed cultured endothelial cells (82). Probably, Western blot analysis of nitrated proteins in the whole retinal samples is not the optimal method for evaluation of focal nitrosative stress induced by IR injury (26), and immunohistochemical assessment of nitrotyrosine immunoreactivity remains the only option for retinal IR-related studies, at least, in rodent models.

In conclusion, IR injury to rat retina is associated with a dramatic increase in cell death, elevated AR expression and sorbitol pathway intermediate accumulation. These changes were prevented or alleviated by the aldose reductase inhibitor fidarestat. The results identify AR as an important therapeutic target for diseases involving IR injury, and provide the rationale for development of fidarestat and other ARIs. 


\section{Acknowledgements}

The study was supported by a grant from Sanwa Kagaku Kenkyusho Co., Ltd. (to I.G.O. and C.D.A.), the Intramural Research Program of the National Institutes of Health/ National Institute of Alcohol Abuse and Alcoholism (to P.P.), the Juvenile Diabetes Research Foundation International Grant 2-2008-149 (to A.B.E), and the American Heart Association Grant (to A.B.E). Dr I.G. Obrosova and Y. Maksimchyk were supported, in part, by the National Institutes of Health Grants DK074517 and DK077141 and the American Diabetes Association grant (all to I.G.O.).

\section{References}

1. Hers HG: The mechanism of the formation of seminal fructose and fetal fructose. Biochim Biophys Acta 37: 127-138, 1960

2. Sato S, Mori K, Wyman M and Kador PF: Dose-dependent prevention of sugar cataracts in galactose-fed dogs by the aldose reductase inhibitor M79175. Exp Eye Res 66: 217-222, 1998.

3. Sun W, Oates PJ, Coutcher JB, Gerhardinger C and Lorenzi M: A selective aldose reductase inhibitor of a new structural class prevents or reverses early retinal abnormalities in experimental diabetic retinopathy. Diabetes 55: 2757-2762, 2006.

4. Drel VR, Pacher P, Ali TK, Shin J, Julius U, El-Remessy AB and Obrosova IG: Aldose reductase inhibitor fidarestat counteracts diabetes-associated cataract formation, retinal oxidativenitrosative stress, glial activation, and apoptosis: Int J Mol Med 21: 667-676, 2008

5. Neuenschwander H, Takahashi Y and Kador PF: Dose-dependent reduction of retinal vessel changes associated with diabetic retinopathy in galactose-fed dogs by the aldose reductase inhibitor M79175. J Ocul Pharmacol Ther 13: 517-528, 1997.

6. Obrosova IG, Minchenko AG, Vasupuram R, White L, Abatan OI, Kumagai AK, Frank RN and Stevens MJ: Aldose reductase inhibitor fidarestat prevents retinal oxidative stress and vascular endothelial growth factor overexpression in streptozotocin-diabetic rats. Diabetes 52: 864-871, 2003.

7. Nakamura J, Kato K, Hamada Y, Nakayama M, Chaya S, Nakashima E, Naruse K, Kasuya Y, Mizubayashi R, Miwa K, Yasuda Y, Kamiya H, Ienaga K, Sakakibara F, Koh N and Hotta N: A protein kinase C-beta-selective inhibitor ameliorates neural dysfunction in streptozotocin-induced diabetic rats. Diabetes 48: 2090-2095, 1999.

8. Kato N, Mizuno K, Makino M, Suzuki T and Yagihashi S: Effects of 15-month aldose reductase inhibition with fidarestat on the experimental diabetic neuropathy in rats. Diabetes Res Clin Pract 50: 77-85, 2000.

9. Keegan A, Jack AM, Cotter MA and Cameron NE: Effects of aldose reductase inhibition on responses of the corpus cavernosum and mesenteric vascular bed of diabetic rats. J Cardiovasc Pharmacol 35: 606-613, 2000

10. Obrosova IG, Van Huysen C, Fathallah L, Cao XC, Greene DA and Stevens MJ: An aldose reductase inhibitor reverses early diabetes-induced changes in peripheral nerve function, metabolism, and antioxidative defense. FASEB J 16: 123-125, 2002.

11. Price SA, Agthong S, Middlemas AB and Tomlinson DR: Mitogen-activated protein kinase p38 mediates reduced nerve conduction velocity in experimental diabetic neuropathy: interactions with aldose reductase. Diabetes 53: 1851-1856, 2004.

12. Schrijvers BF, De Vriese AS and Flyvbjerg A: From hyperglycemia to diabetic kidney disease: the role of metabolic, hemodynamic, intracellular factors and growth factors/cytokines. Endocr Rev 25: 971-1010, 2004.

13. Drel VR, Pacher P, Stevens MJ and Obrosova IG: Aldose reductase inhibition counteracts nitrosative stress and poly (ADP-ribose) polymerase activation in diabetic rat kidney and high-glucose-exposed human mesangial cells. Free Radic Biol Med 40: 1454-1465, 2006

14. Lee AY, Chung SK and Chung SS: Demonstration that polyol accumulation is responsible for diabetic cataract by the use of transgenic mice expressing the aldose reductase gene in the lens. Proc Natl Acad Sci USA 92: 2780-2784, 1995.
15. Yagihashi S, Yamagishi SI, Wada Ri R, Baba M, Hohman TC, Yabe-Nishimura $\mathrm{C}$ and Kokai Y: Neuropathy in diabetic mice overexpressing human aldose reductase and effects of aldose reductase inhibitor. Brain 124: 2448-2458, 2001

16. Ho EC, Lam KS, Chen YS, Yip JC, Arvindakshan M, Yamagishi S, Yagihashi S, Oates PJ, Ellery CA, Chung SS and Chung SK: Aldose reductase-deficient mice are protected from delayed motor nerve conduction velocity, increased c-Jun NH2terminal kinase activation, depletion of reduced glutathione, increased superoxide accumulation, and DNA damage. Diabetes 55: 1946-1953, 2006

17. Cheung AK, Fung MK, Lo AC, Lam TT, So KF, Chung SS and Chung SK: Aldose reductase deficiency prevents diabetesinduced blood-retinal barrier breakdown, apoptosis, and glial reactivation in the retina of $\mathrm{db} / \mathrm{db}$ mice. Diabetes 54: 3119-3125, 2005.

18. Srivastava S, Vladykovskaya E, Barski OA, Spite M, Kaiserova K, Petrash JM, Chung SS, Hunt G, Dawn B and Bhatnagar A: Aldose reductase protects against early atherosclerotic lesion formation in apolipoprotein E-null mice. Circ Res 105: 793-802, 2009.

19. Tammali R, Reddy AB, Ramana KV, Petrash JM and Srivastava SK: Aldose reductase deficiency in mice prevents azoxymethane-induced colonic preneoplastic aberrant crypt foci formation. Carcinogenesis 30: 799-807, 2009.

20. Reddy AB, Srivastava SK and Ramana KV: Anti-inflammatory effect of aldose reductase inhibition in murine polymicrobial sepsis. Cytokine 48: 170-176, 2009.

21. Yadav UC, Naura AS, Aguilera-Aguirre L, Ramana KV Boldogh I, Sur S, Boulares HA and Srivastava SK: Aldose reductase inhibition suppresses the expression of Th2 cytokines and airway inflammation in ovalbumin-induced asthma in mice. J Immunol 183: 4723-4732, 2009.

22. Yadav UC, Srivastava SK and Ramana KV: Aldose reductase inhibition prevents endotoxin-induced uveitis in rats. Invest Ophthalmol Vis Sci 48: 4634-4642, 2007.

23. Hwang YC, Kaneko M, Bakr S, Liao H, Lu Y, Lewis ER, Yan S, Ii S, Itakura M, Rui L, Skopicki H, Homma S, Schmidt AM, Oates PJ, Szabolcs M and Ramasamy R: Central role for aldose reductase pathway in myocardial ischemic injury. FASEB $\mathrm{J} 18$ : 1192-1199, 2004.

24. Ananthakrishnan R, Kaneko M, Hwang YC, Quadri N, Gomez T, Li Q, Caspersen C and Ramasamy R: Aldose reductase mediates myocardial ischemia-reperfusion injury in part by opening mitochondrial permeability transition pore. Am J Physiol Heart Circ Physiol 296: H333-H341, 2009.

25. Tang WH, Kravtsov GM, Sauert M, Tong XY, Hou XY, Wong TM, Chung SK and Man Chung SS: Polyol pathway impairs the function of SERCA and RyR in ischemic-reperfused rat hearts by increasing oxidative modifications of these proteins. J Mol Cell Cardiol (In press).

26. Cheung AK, Lo AC, So KF, Chung SS and Chung SK: Gene deletion and pharmacological inhibition of aldose reductase protect against retinal ischemic injury. Exp Eye Res 85: 608-616, 2007.

27. Agardh CD, Agardh E, Obrosova IG and Smith ML: The aldose reductase inhibitor fidarestat suppresses ischemia-reperfusioninduced inflammatory response in rat retina. Pharmacology 84: 257-263, 2009

28. Junk AK, Mammis A, Savitz SI, Singh M, Roth S, Malhotra S, Rosenbaum PS, Cerami A, Brines $M$ and Rosenbaum DM: Erythropoietin administration protects retinal neurons from acute ischemia-reperfusion injury. Proc Natl Acad Sci USA 99: 10659-10664, 2002.

29. Russo R, Rotiroti D, Tassorelli C, Nucci C, Bagetta G, Bucci MG, Corasaniti MT and Morrone LA: Identification of novel pharmacological targets to minimize excitotoxic retinal damage. Int Rev Neurobiol 85: 407-423, 2009.

30. Hotta N, Koh N, Sakakibara F, Nakamura J, Hara T, Hamada Y, Fukasawa H, Kakuta $\mathrm{H}$ and Sakamoto N: Effect of an aldose reductase inhibitor on abnormalities of electroretinogram and vascular factors in diabetic rats. Eur J Pharmacol 326: 45-51, 1997.

31. Block F and Schwarz M: The b-wave of the electroretinogram as an index of retinal ischemia. Gen Pharmacol 30: 281-287, 1998.

32. Kim KY, Ju WK and Neufeld AH: Neuronal susceptibility to damage: comparison of the retinas of young, old and old/caloric restricted rats before and after transient ischemia. Neurobiol Aging 25: 491-500, 2004. 
33. Drel VR, Xu W, Zhang J, Kador PF, Ali TK, Shin J, Julius U, Slusher B, El-Remessy AB and Obrosova IG: Poly(ADPribose)polymerase inhibition counteracts cataract formation and early retinal changes in streptozotocin-diabetic rats. Invest Ophthalmol Vis Sci 50: 1778-1790, 2009.

34. Barber AJ, Lieth E, Khin SA, Antonetti DA, Buchanan AG and Gardner TW: Neural apoptosis in the retina during experimental and human diabetes. Early onset and effect of insulin. J Clin Invest 102: 783-791, 1998.

35. Wilson CA, Berkowitz BA, Funatsu H, Metrikin DC, Harrison DW, Lam MK and Sonkin PL: Blood-retinal barrier breakdown following experimental retinal ischemia and reperfusion. Exp Eye Res 61: 547-557, 1995.

36. Rota R, Chiavaroli C, Garay RP and Hannaert P: Reduction of retinal albumin leakage by the antioxidant calcium dobesilate in streptozotocin-diabetic rats. Eur J Pharmacol 495: 217-224, 2004.

37. Steigerwalt R, Belcaro G, Cesarone MR, Di Renzo A, Grossi MG Ricci A, Dugall M, Cacchio M and Schönlau F: Pycnogenol improves microcirculation, retinal edema, and visual acuity in early diabetic retinopathy. J Ocul Pharmacol Ther 25: 537-540, 2009.

38. Kato N, Yashima S, Suzuki T, Nakayama Y and Jomori T: Long-term treatment with fidarestat suppresses the development of diabetic retinopathy in STZ-induced diabetic rats. J Diabetes Complications 17: 374-379, 2003.

39. Zheng L, Gong B, Hatala DA and Kern TS: Retinal ischemia and reperfusion causes capillary degeneration: similarities to diabetes. Invest Ophthalmol Vis Sci 48: 361-367, 2007.

40. Campochiaro PA: Retinal and choroidal neovascularization. J Cell Physiol 184: 301-310, 2000.

41. Frank RN: Diabetic retinopathy. N Engl J Med 350: 48-58, 2004.

42. Tsujikawa A, Kiryu J, Dong J, Yasukawa T, Suzuma I, Takagi H and Ogura Y: Quantitative analysis of diabetic macular edema after scatter laser photocoagulation with the scanning retinal thickness analyzer. Retina 19: 59-64, 1999.

43. Gustavsson C, Agardh CD, Hagert P and Agardh E: Inflammatory markers in nondiabetic and diabetic rat retinas exposed to ischemia followed by reperfusion. Retina 28: 645-652, 2008.

44. Obrosova IG and Stevens MJ: Effect of dietary taurine supplementation on GSH and NAD(P)-redox status, lipid peroxidation, and energy metabolism in diabetic precataractous lens. Invest Ophthalmol Vis Sci 40: 680-688, 1999.

45. Obrosova IG, Stevens MJ and Lang HJ: Diabetes-induced changes in retinal NAD-redox status: pharmacological modulation and implications for pathogenesis of diabetic retinopathy. Pharmacology 62: 172-180, 2001.

46. El-Remessy AB, Al-Shabrawey M, Khalifa Y, Tsai NT, Caldwell RB and Liou GI: Neuroprotective and blood-retinal barrier-preserving effects of cannabidiol in experimental diabetes. Am J Pathol 168: 235-244, 2006.

47. Iwata K, Matsuno K, Nishinaka T, Persson C and YabeNishimura C: Aldose reductase inhibitors improve myocardial reperfusion injury in mice by a dual mechanism. J Pharmacol Sci 102: 37-46, 2006.

48. Yagihashi S, Mizukami H, Ogasawara S, Yamagishi SI, Nukada H, Kato N, Hibi C, Chung S and Chung S: The role of the polyol pathway in acute kidney injury caused by hindlimb ischaemia in mice. J Pathol (In press).

49. Schmidt RE, Dorsey DA, Beaudet LN, Plurad SB, Parvin CA, Yarasheski KE, Smith SR, Lang HJ, Williamson JR and Ido Y: Inhibition of sorbitol dehydrogenase exacerbates autonomic neuropathy in rats with streptozotocin-induced diabetes. J Neuropathol Exp Neurol 60: 1153-1169, 2001.

50. Kador PF, Inoue J, Secchi EF, Lizak MJ, Rodriguez L, Mori K, Greentree W, Blessing K, Lackner PA and Sato S: Effect of sorbitol dehydrogenase inhibition on sugar cataract formation in galactose-fed and diabetic rats. Exp Eye Res 67: 203-208, 1998.

51. Obrosova IG, Fathallah L and Lang HJ: Interaction between osmotic and oxidative stress in diabetic precataractous lens: studies with a sorbitol dehydrogenase inhibitor. Biochem Pharmacol 58: 1945-1954, 1999.

52. Obrosova IG, Fathallah L, Lang HJ and Greene DA: Evaluation of a sorbitol dehydrogenase inhibitor on diabetic peripheral nerve metabolism: a prevention study. Diabetologia 42: 1187-1194, 1999.

53. Schmidt RE, Dorsey DA, Beaudet LN, Parvin CA, Yarasheski KE, Smith SR, Williamson JR, Peterson RG and Oates PJ: A potent sorbitol dehydrogenase inhibitor exacerbates sympathetic autonomic neuropathy in rats with streptozotocin-induced diabetes. Exp Neurol 192: 407-419, 2005.
54. Tilton RG, Chang K, Nyengaard JR, Van den Enden M, Ido Y and Williamson JR: Inhibition of sorbitol dehydrogenase. Effects on vascular and neural dysfunction in streptozocin-induced diabetic rats. Diabetes 44: 234-242, 1995.

55. Ido Y, Nyengaard JR, Chang K, Tilton RG, Kilo C, Mylari BL, Oates PJ and Williamson JR: Early neural and vascular dysfunctions in diabetic rats are largely sequelae of increased sorbitol oxidation. Antioxid Redox Signal 12: 39-51, 2010.

56. Cameron NE, Cotter MA, Basso M and Hohman TC: Comparison of the effects of inhibitors of aldose reductase and sorbitol dehydrogenase on neurovascular function, nerve conduction and tissue polyol pathway metabolites in streptozotocin-diabetic rats. Diabetologia 40: 271-281, 1997.

57. Ng TF, Lee FK, Song ZT, Calcutt NA, Lee AY, Chung SS and Chung SK: Effects of sorbitol dehydrogenase deficiency on nerve conduction in experimental diabetic mice. Diabetes 47: 961-966, 1998

58. Li Q, Hwang YC, Ananthakrishnan R, Oates PJ, Guberski D and Ramasamy R: Polyol pathway and modulation of ischemiareperfusion injury in Type 2 diabetic BBZ rat hearts. Cardiovasc Diabetol 7: 33, 2008.

59. Obrosova IG: Increased sorbitol pathway activity generates oxidative stress in tissue sites for diabetic complications. Antioxid Redox Signal 7: 1543-1552, 2005.

60. Obrosova IG and Fathallah L: Evaluation of an aldose reductase inhibitor on lens metabolism, ATPases and antioxidative defense in streptozotocin-diabetic rats: an intervention study. Diabetologia 43: 1048-1055, 2000.

61. Hall KE, Liu J, Sima AA and Wiley JW: Impaired inhibitory Gprotein function contributes to increased calcium currents in rats with diabetic neuropathy. J Neurophysiol 86: 760-770, 2001.

62. Lal S, Szwergold BS, Taylor AH, Randall WC, Kappler F, Wells-Knecht K, Baynes JW and Brown TR: Metabolism of fructose-3-phosphate in the diabetic rat lens. Arch Biochem Biophys 318: 191-199, 1995.

63. Phillips SA, Mirrlees D and Thornalley PJ: Modification of the glyoxalase system in streptozotocin-induced diabetic rats. Effect of the aldose reductase inhibitor Statil. Biochem Pharmacol 46: 805-811, 1993.

64. Hasuike Y, Nakanishi T, Otaki Y, Nanami M, Tanimoto T, Taniguchi $\mathrm{N}$ and Takamitsu $\mathrm{Y}$ : Plasma 3-deoxyglucosone elevation in chronic renal failure is associated with increased aldose reductase in erythrocytes. Am J Kidney Dis 40: 464-471, 2002.

65. Nagaraj RH, Prabhakaram M, Ortwerth BJ and Monnier VM: Suppression of pentosidine formation in galactosemic rat lens by an inhibitor of aldose reductase. Diabetes 43: 580-586, 1994.

66. Hamada Y, Nakamura J, Naruse K, Komori T, Kato K, Kasuya Y, Nagai R, Horiuchi S and Hotta N: Epalrestat, an aldose reductase ihibitor, reduces the levels of Nepsilon-(carboxymethyl)lysine protein adducts and their precursors in erythrocytes from diabetic patients. Diabetes Care 23: 1539-1544, 2000.

67. Ramana KV, Friedrich B, Tammali R, West MB, Bhatnagar A and Srivastava SK: Requirement of aldose reductase for the hyperglycemic activation of protein kinase $\mathrm{C}$ and formation of diacylglycerol in vascular smooth muscle cells. Diabetes 54: 818-829, 2005.

68. Uehara K, Yamagishi S, Otsuki S, Chin S and Yagihashi S: Effects of polyol pathway hyperactivity on protein kinase C activity, nociceptive peptide expression, and neuronal structure in dorsal root ganglia in diabetic mice. Diabetes 53: 3239-3247, 2004.

69. Zatechka DS Jr, Kador PF, Garcia-Castiñeiras S and Lou MF: Diabetes can alter the signal transduction pathways in the lens of rats. Diabetes 52: 1014-1022, 2003.

70. Obrosova IG, Pacher P, Szabó C, Zsengeller Z, Hirooka H, Stevens MJ and Yorek MA: Aldose reductase inhibition counteracts oxidative-nitrosative stress and poly(ADP-ribose) polymerase activation in tissue sites for diabetes complications. Diabetes 54: 234-242, 2005.

71. Ramos KM, Jiang Y, Svensson CI and Calcutt NA: Pathogenesis of spinally mediated hyperalgesia in diabetes. Diabetes 56 : 1569-1576, 2007

72. Ramana KV, Friedrich B, Srivastava S, Bhatnagar A and Srivastava SK: Activation of nuclear factor-kappaB by hyperglycemia in vascular smooth muscle cells is regulated by aldose reductase. Diabetes 53: 2910-2920, 2004.

73. Ji D, Li GY and Osborne NN: Nicotinamide attenuates retinal ischemia and light insults to neurones. Neurochem Int 52: 786-798, 2008. 
74. Sakai Y, Tanaka T, Seki M, Okuyama S, Fukuchi T, Yamagata K, Takei N, Nawa $\mathrm{H}$ and Abe H: Cyclooxygenase-2 plays a critical role in retinal ganglion cell death after transient ischemia: realtime monitoring of RGC survival using Thy-1-EGFP transgenic mice. Neurosci Res 65: 319-325, 2009.

75. Berger S, Savitz SI, Nijhawan S, Singh M, David J, Rosenbaum PS and Rosenbaum DM: Deleterious role of TNF-alpha in retinal ischemia-reperfusion injury. Invest Ophthalmol Vis Sci 49: 3605-3610, 2008.

76. Hata N, Oshitari T, Yokoyama A, Mitamura Y and Yamamoto S Increased expression of IRE1alpha and stress-related signal transduction proteins in ischemia-reperfusion injured retina. Clin Ophthalmol 2: 743-752, 2008.

77. Naruse K, Nakamura J, Hamada Y, Nakayama M, Chaya S, Komori T, Kato K, Kasuya Y, Miwa K and Hotta N: Aldose reductase inhibition prevents glucose-induced apoptosis in cultured bovine retinal microvascular pericytes. Exp Eye Res 71: 309-315, 2000 .

78. Takamura Y, Tomomatsu T, Kubo E, Tsuzuki S and Akagi Y: Role of the polyol pathway in high glucose-induced apoptosis of retinal pericytes and proliferation of endothelial cells. Invest Ophthalmol Vis Sci 49: 3216-3223, 2008.
79. Pacher P, Beckman JS and Liaudet L: Nitric oxide and peroxynitrite in health and disease. Physiol Rev 87: 315-424, 2007.

80. Zhang B, Rusciano D and Osborne NN: Orally administered epigallocatechin gallate attenuates retinal neuronal death in vivo and light-induced apoptosis in vitro. Brain Res 1198: 141-152, 2008.

81. El-Remessy AB, Bartoli M, Platt DH, Fulton D and Caldwell RB: Oxidative stress inactivates VEGF survival signaling in retinal endothelial cells via PI 3-kinase tyrosine nitration. J Cell Sci 118: 243-252, 2005.

82. El-Remessy AB, Abou-Mohamed G, Caldwell RW and Caldwell RB: High glucose-induced tyrosine nitration in endothelial cells: role of eNOS uncoupling and aldose reductase activation. Invest Ophthalmol Vis Sci 44: 3135-3143, 2003. 